\title{
The Courtroom as an Arena of Ideological and Political Confrontation: The Chicago Eight Conspiracy Trial
}

\author{
Awol Allo ${ }^{1}$ iD \\ Accepted: 23 November 2021 / Published online: 4 December 2021 \\ (C) The Author(s) 2021
}

\begin{abstract}
Normative theories of law conceive the courtroom as a geometrically delineated, politically neutral, and linguistically transparent space designed for a fair and orderly administration of justice. The trial, the most legalistic of all legal acts, is widely regarded as a site of truth and justice elevated above and beyond the expediency of ideology and politics. These conceptions are further underpinned by certain normative understandings of sovereignty, the subject, and politics where sovereignty is conceived as self-instituting and self-limiting; the subject is understood as an autonomous and rational being capable of self-consciousness and self-representation; and politics is posited as the exercise of reason in the public sphere. In this article, I argue that such a normative conceptualization of the criminal trial and the courtroom not only ignores structures of power and privilege that produce inequalities but also forecloses possibilities for transformative judicial praxis. Drawing on the 1969-1970 trial of eight radical activists accused of conspiring to incite a riot at the 1968 Democratic National Convention in Chicago, the article argues for a performative re-conceptualization of sovereignty, the subject, and the law as indeterminate, unpredictable, and open-ended discursive formations. The article demonstrates how the accused, working with and against legal doctrines, norms, and discourses, rethought normative conceptions of sovereignty, law, and subjectivity as contingent power-knowledge constellations that are open, unpredictable, and un-closable.
\end{abstract}

Keywords The Chicago Conspiracy Trial · Chicago 1968 protests · Political trials · Performativity $\cdot$ Rupture $\cdot$ Utopia in the courtroom

The Prosecution: Mr Hoffman, isn't it a fact that one of the reasons why you came to Chicago was simply to wreck American society?

The Witness: My feeling at the time, and still is, that society is going to wreck itself. I said that on a number of occasions that our role is to survive while the

Awol Allo

a.k.allo@keele.ac.uk

1 School of Law, University of Keele, Newcastle under-Lyme, Staffordshire ST5 5BG, UK 
society comes tumbling down around us; our role is to survive. We have to learn how to defend ourselves, given this type of society, because of the war in Vietnam, because of racism, because of the attack on the Cultural Revolution-in fact, because of this trial.

\section{Introduction}

In September 1969, the United States government announced a carefully crafted charge against eight radical activists who represented the various spectrums of the dissent of the 1960s in what came to be known as the Chicago Eight Conspiracy Trial. The eight defendants-John Froines and David Dellinger of the National Mobilization Committee to End the War in Vietnam (MOBE); Abbie Hoffman and Jerry Rubin of the Youth International Party; Rennie Davis and Tom Hayden of the Students for Democratic Society (SDS); Bobby Seale of the Black Panther Party; and Lee Weiner, a doctoral candidate at Northwestern University-were charged under Title 18 of the Civil Rights Act of 1968 with conspiracy to incite a riot during the 1968 Democratic National Convention in Chicago. Coming hot on the heels of a particularly tumultuous period, which saw the assassinations of the Rev. Dr Martin Luther King Jr. and Robert Kennedy, the Tet Offensive, widespread urban riots, the rise of the Black Panthers and other Black Power movements, and growing student protests on university campuses, the Chicago Conspiracy Trial brought the ideological and political confrontation of the 1960s into the courtroom. Staged between September 1969 and February 1970 in the district courthouse in Chicago, the Chicago Eight Conspiracy Trial has been widely recognised as 'one of the most unusual courtroom spectacles in American history,' and served as a microcosm of the larger political and cultural confrontations of the 1960s (Linder 2017).

Both the accused and the accuser saw the trial as an arena of political and ideological struggle. The Nixon administration saw the movements of the 1960s as 'Barbarians at the Gate' - an assemblage of communist agitators, mindless rioters, and extreme nationalists united in their desire 'to wreck American society' and remake it in their image (Lahav 2004, p. 383). The defendants, on their part, saw the trial as a continuation of the war and state sanctioned violence against dissent and opposition by legal means. The courtroom became a battleground for competing ideological views on the meaning of society, legitimate authority, law and legality, and the normative legitimacy of the liberal capitalist order. The confrontation between the state and the activists engaged with some of the most enduring social and political themes and exposed the schism between the cherished values and principles underpinning American constitutional democracy and its practices of slavery, Jim Crow, racism, police brutality, and militarism. The exchange between the deliberately disobedient defendants and the representatives of the state, complete with 'grotesque scenes, amazing spectacles, poignant and intense dialogues', subjected establishment values, norms, and practices to disruptive and transformative critique (Lahav 2004, p. 385).

From a normative theoretical perspective, the criminal trial is a legal event in which the accused is called to account by the authorities according to established norms and procedures (Duff et al. 2004, 2006; Duff 2018). The proper purpose and 
function of the criminal trial is to establish the truth of what happened, determine the guilt or innocence of the accused, and render justice (Duff et al. 2004, 2006). In 'Eichmann in Jerusalem', political theorist Hannah Arendt puts the normative case for the criminal trial in these eloquent terms: 'the purpose of the trial is to render justice and nothing else. Even the noblest of ulterior purposes can only detract from the law's main business: to weigh the charges against the accused, to render judgment, and to mete out due punishment' (Arendt 1965, p. 253). In a major project aimed at developing a normative theory of the criminal trial, Duff and others identify the notion of calling to account as the central feature of a normative theory of the trial (Duff et al. 2006, p. 3). They argue that in order for public authority to justify its authority to call individuals to account and pass a sentence, individuals must see themselves as authors of the law and must be treated as both addressors and addressee of the rules and principles applied during the trial. Arguing that the social contract model is insufficient and must be complemented by the deliberative model, Jurgen Habermas emphasises the importance of allowing citizens a voice as central to the legitimacy of the modern legal order: "citizens should always be able to understand themselves as authors of the law to which they are subject as addressees' (Habermas 1996, p. 449).

Central to these normative positions is the assumption that the accused, both as an addressee and addressor of the norms and standards applied by the trial, accepts the legitimacy of these norms and obeys the authority of the institutions that apply them (Duff et al. 2004, 2006). But what if a defendant called to account for criminal wrongdoing refuses to accept the legitimacy and authority of the state and its founding documents? If calling to account also means giving the accused a central role in the trial, treating them as responsible agents who must be allowed to give account of themselves, the indictment, the norms applied to them, and the political community that is calling them to account, what happens when the courtroom encounters a defendant who rejects the normative legitimacy of the political order and is keen to use the trial to engage in a radical critique of the existing political and economic arrangements.

This article is a critical exploration of the defendants' judicial praxis, focusing on the logic of disruption, transformation, and rupture that animated their strategic political engagement with the law. The article argues that despite law's normative claims about the proper purposes and functions of the criminal trial, the latter can be used in creative and subversive ways to pursue transformative political and social goals. The article unfolds in four stages. First, I will provide an overview of the factual background and the political context within which the trial took place. Second, I will examine the logic of disruption and interruption that underpinned the defendant's strategic engagement with the law, focusing on the ways in which the defendants deployed the trial's spatial, material, and temporal openness to engage in a radical critique of the United States government and its policies, putting the American body-politic in contradiction to its cherished values and principles. Third, I will consider the logic of transformation at work in this trial, demonstrating the ways in which the devices of law and justice were synchronized with utopian imaginations to concretize and solidify the defendants' ideas of a fairer, equal, and just society. Finally, drawing on insights that emerge from these examples, the article attempts to 
draw some general conclusions about the use of the courtroom as a site of political and ideological critique. The analysis presented will demonstrate that contrary to normative legal theories which take the social contract and the deliberative model of the trial as their points of departure for understanding the relationship between the subject and the sovereign, a performative approach to legal spaces, institutions and discourses can enhance our understandings of contested trials and assess law's potential as a tool of progressive social goals.

\section{'The Whole World is Watching': Setting the Stage}

The 1960s was a tumultuous, dynamic, and eventful decade in American history that continues to fascinate historians and cultural critics. While it was a decade that saw sustained economic growth, it was also a period that represented one of the most fundamental challenges to the prevailing political, economic, and social arrangements. Politically and culturally, 1968 was perhaps one of the most turbulent and contentious years of the twentieth century, a year widely seen as 'a touchstone in struggles over the meaning of the American past and the direction of the nation's future' (Farber and Bailey 2001, p. xi). The Democratic National Convention held in Chicago in August 1968 and the violent confrontation between the authorities and protestors is regarded as one of the most significant political and cultural events of 1968.

When the Democratic National Committee announced Chicago as the host city for the 1968 Democratic National Convention, several radical social movements announced their intentions to stage protests during the Convention in Chicago to highlight their respective grievances and causes (Farber 1988, p. 116). The National Mobilization Committee to End the War in Vietnam (MOBE), an umbrella organization established by several anti-war groups to coordinate mass demonstrations; and the Youth International Party (the Yippies), a revolutionary counter-cultural offshoot of the anti-war movements committed to the realization of a new kind of society, were among the most prominent movements with significant role in the protests (Farber 1988, p. 69; Sharma 2016, p. 1). The MOBE planned two major marches, one large-scale rally, and a series of workshops and seminars in the city to raise awareness and build mass political support for the movement (Mara 2010, p. 33). The Yippies, on the other hand, saw the Convention as an important opportunity to stage a 'Festival of Life' intended to announce the emergence of a new culture and a new society committed to new and different ways of being and acting. The countercultural group wanted to use the Convention as a platform to "celebrate the birth of free America' (McCarthy and McMillian 2010, p. 133).

In the Spring of 1968, the political upheaval gripping America reached unprecedented levels (Farber 1988, p. 117). Chicago authorities, who saw the Convention as pivotal to showcase their city, took an antagonistic and aggressive position towards protestors, asserting that 'the streets of Chicago would not be surrendered to outside agitators' (Danver 2011, p. 1011). The city refused or stalled permit requests by MOBE and Yippies for marches, and imposed a curfew of 11 pm (Danver 2011, p. 1011). Citing dubious intelligence report of violence, Chicago Mayor Richard J. 
Daley deployed 12,000 police officers, 5,600 members of the state National Guard and 5,000 army troops, setting the stage for the assault and violence that defined the 1968 Democratic National Convention (Achenbach 2018). For five days, the more than 10,000 police officers went berserk on the streets of Chicago, clubbing, gassing and assaulting protestors in a 'state of excited anger' (Taylor and Morris 2018; Kusch 2008, p. 135). The unprovoked assault and violence against protestors on the streets of Chicago received significant media coverage. Protestors chanted, 'The Whole World is Watching', a rallying cry that became 'the ultimate slogan of Chicago 1968' (Schultz 1993, p. xi).

In December 1968, the U.S. National Commission on the Causes and Prevention of Violence set up a commission to enquire into the causes of the violence in Chicago. Convened by Daniel Walker, a well-respected Chicago lawyer, the Commission concluded that the police perpetrated an organized, unrestrained, and indiscriminate attack on protestors (Farber 2019, p. 143). The 362-page report-compiled 'based on a review of over 20,000 pages of statements from 3437 eyewitnesses and participants' - concluded: 'individual policemen, and lots of them, committed violent acts far in excess of the requisite force for crowd dispersal or arrest. To read dispassionately the hundreds of statements describing at first hand the events of Sunday and Monday nights is to become convinced of the presence of what can only be called a police riot' (Casey-Maslen 2014, p. 69). The Department of Justice enquiry into the violence reached a similar conclusion, finding no grounds for prosecution of protestors. The then Attorney General, Ramsey Clark, instead asked the US Attorney's Office in Chicago to investigate possible violations of civil rights by Chicago Police.

Chicago authorities, however, pushed a different narrative of what transpired in their city. A report by the Daley administration blamed 'outside agitators' and 'revolutionaries' who came to Chicago 'for the avowed purpose of a hostile confrontation with law enforcement' and called for prosecution (Kusch 2004, p. 118-119). In January 1969, Richard Nixon was inaugurated and his new Attorney General, John Mitchell, welcomed the opportunity to put leaders of key protest movements on trial (Popovici 2018). On March 20, 1969, a grand jury returned indictments against the eight defendants.

The trial began in the Federal District Court in Chicago before Judge Julius Jennings Hoffman. The state was represented by U.S. Attorney Thomas Aquinas Foran, and his assistant Richard Schultz. Foran was a 'mainstream Democrat' and an associate of Mayor Richard Daley, who once described him as 'one of the greatest attorneys in the country and the finest man I have met in public or private life' (Linder 2017). Schultz was an ambitious assistant prosecutor who was seen as 'the government's pit bull' (Linder 2017). Both saw the courtroom as a battleground against what they called 'evil men' committed to humiliating the United States government and achieving their aims through insurrection and revolution (Clavir and Spitzer 1971, p. 569). In their opening statement, Foran and Schultz promised the jury evidence that would prove a dangerous conspiracy by the eight men to incite people 'against the police department, the city officials, the National Guard and the military, and against the convention itself' (Clavir and Spitzer 1971, p. 11). The defence team, on the other hand, comprised of William Kunstler of New York and Leonard 
Weinglass of New Jersey, veterans of the 'cause lawyering' movement with extensive experience representing anti-war, anti-racist, and social justice movements across the country. In their opening statement, they promised the jury evidence of a conspiracy by the government in which Chicago police engineered a riot and 'embarked on an organised conspiracy of berserk brutal action against demonstrators' (Clavir and Spitzer 1971, p. 16).

Both the government and the defendants saw the courtroom as an arena of political and ideological confrontation and used the trial to advance their respective political goals. The government used the trial to delegitimize the character of the accused and their causes and vindicate the government's conduct and policies. With the assistance of the Judge, the prosecution demonised the accused as 'professional extremists,' 'insurrectionists,' 'lairs,' 'obscene haters' etc., and framed the defendants as out-of-control feral youth calling for revolution and insurrection and their movements as deviant and dangerous. The defendants, on their part, saw the trial as the continuation of the state sanctioned violence against the anti-war, anti-racist and counter-cultural movements by legal means, where the court system is tactically mobilized to tie up the time and energy of some of the most vigorous movements of the 1960s. William Kunstler compared the trial of his clients with the trials of Jesus and Socrates, arguing that all tyrants learn to silence dissent and opposition 'through some semblance of legality than without that pretence' (Stewart et al. 2011, p. 241-242). Lee Weiner, one of the eight defendants, summed up the political nature of the trial as follows:

Using the artificial, state-controlled rules of the court, the U.S. government's prosecutors and judge will attempt to interpret the people's insurrection in Chicago as the private and deliberate manipulation of eight evil men. The government will be desperate to play down the independent action of thousands of people who openly resisted illegitimate political and police power. The trial, therefore, must blur and soften the contours of what actually happened, and instead focus upon and magnify the roles of these eight men in particular. The alternative image - one of a popular insurrection rooted in the experience and desires of people that was put down by the deliberate exercise of statecontrolled violence - too clearly focuses public attention on what America is all about. The government effort is intended to punish and frighten a growing, insurgent mass movement of both the young and concerned adults, and to protect the official myths of political reality in America. (Babeox and Babeox 1969, p. 198)

A critical part of the defence strategy was to defend themselves in political terms, through a strategic-political engagement with the law, to expose the contradiction at the heart of the system. From the beginning, they declared 'The whole world is watching', as they sought to reframe the trial as a vehicle of ideological confrontation and articulate a robust defence of the peace movement and the counter-cultural revolution. Raising the stakes, Kunstler concluded his opening statement by noting: 'At one point it was the spear; at another time it was the noose; and today or in August of 1968 it was the billy club wielded indiscriminately against demonstrators, newsmen, women, children, young men, old men, here in the streets of Chicago. 
Dissent died here for a moment during the Democratic National Convention. What happens, in this case, may determine whether it is moribund' (Clavir and Spitzer 1971, pp. 16-17).

In the next three sections, I will examine three scenes from the trial to demonstrate how the defendants used the judicial space to advance their own ideological and political views, focusing on the logic of disruption and transformation deployed to open up space and filter narratives of resistance into the court of public opinion and the judicial record.

\section{Scene I: 'The Judge is Inciting a Riot': Rupture in the Courtroom}

On January 23, 1970, Defence Attorney Leonard Weinglass called Rene Davis, one of the eight defendants, to the witness stand, for a direct examination. When asked about his occupation, Mr Davis stated, 'since 1967 my primary work and concern has been ending the war in Vietnam' (Clavir and Spitzer 1971, p. 467). Mr Weinglass then asked Davis to 'relate to the Court and Jury the words that you spoke, as best as you can recall' at the meeting of 'The Resistance' on November 20, 1967, at the University of Chicago. Davis replied, 'I began by holding up a small steel ball that was green, about the size of a tennis ball, and I said, "This bomb was dropped on a city of 100,000 people, a city called Nam Ding, which is about sixty-five miles south of Hanoi," I said, "It was dropped by an American fighter jet, an F-105" (Clavir and Spitzer 1971, p. 467). The open-ended nature of the question enabled Davis to turn the courtroom into a mini seminar on the Vietnam War, presenting himself as a prime witness to the devastation he witnessed. He told the Court and the jury how he travelled to Vietnam and saw 'pagodas that had been gutted, schoolhouses that had been razed, population centres that had been levelled', despite the government's claims of targeting only militants (Clavir and Spitzer 1971, pp. 467-468). After Davis offered an account of the horrific effect of the war on the civilian population in Vietnam, a theme central to the defendants' political message, Weinglass directed Davis' attention to an object, which Davis identified as 'the bomb I brought back from Vietnam' (Clavir and Spitzer 1971, p. 468). Weinglass then asked the Court to offer the bomb into evidence, provoking a furious objection from the prosecution. What follows is a confrontation that unfolded after the court upheld the prosecution's objection, a scene that brilliantly encapsulates the impossibility of communication and understanding between the accused and the accuser within the narrowly circumscribed idiom of the criminal trial.

Prosecution: Your Honour, the Government objects to this exhibit for the following reasons. The Vietnamese war, your Honour, has nothing whatsoever to do with the charges in this indictment. The Vietnamese War, which is a major difficulty of this country and a major concern of every citizen in this country, has nothing whatsoever to do with whether or not people in the United States have a right to travel in interstate commerce to incite a riot. The charges in this indictment your Honour, have nothing to do with this type of testimony or this kind of concept. 
The Court: Objection sustained.

Mr. Kunstler: Your Honour, at this point I would like to move for a mistrial

The Court: I deny the motion.

Mr Rubin: You haven't heard it yet.

The Court: Oh, there is no ground for a mistrial.

Mr. Kunstler: But, your Honour--

The Court: I direct the marshal to have this man sit down.

Mr. Kunstler: Every time I make a motion am I going to be thrown in my seat when I argue it?

Mr. Dellinger: Force and violence. The judge is inciting a riot by asking the marshal to have him sit down.

The Court: That man's name is Dellinger?

Marshal: Will you be quiet, Mr. Dellinger?

Mr. Dellinger: After such hypocrisy I don't particularly feel like being quiet. I said before the judge was the chief prosecutor, and he's proved the point.

The Court: Will you remain quiet? Will you remain quiet, sir?

Mr. Dellinger: You let Foran give a foreign policy speech, but when he tries to answer it, you interrupt him and won't let him speak. There's no pretence of fairness in this court. All you're doing is employing a riot--employing force and violence to try to keep me quiet. Just like you gagged Bobby Seale because you couldn't afford to listen to the truth that he was saying to you. You're accusing me. I'm a pacifist.

Marshal: Sit down, please, and be quiet.

Mr. Dellinger: I am employing nonviolence, and you're accusing me of violence, and you have a man right here, backed up by guns, jails, and force and violence. That is the difference between us.

Marshal: Will you sit down?

The Court: Will you continue, please, with the direct examination of this witness?

Mr. Dellinger: There goes the violence right there.

Mr. Kunstler: That's the Government in operation, your Honor, as it has been throughout this trial.

Witness: Your Honor, that is my sister they are taking out of the courtroom

The Court: Even your sister -

Mr. Kunstler: Your Honor, must we always have this, the force and power of the Government?

Prosecution: Your Honor, traditionally in American law, cases are tried in a courtroom by the participants in the trial, not the audience, not spectators, not by shouting and screaming. This is the American judicial system, and it's worked very well for two hundred years, and it's not going to change now for these people.

Mr. Dellinger: Yes, kept the black people in slavery for two hundred years and wiped out the Indians, and kept the poor people in problems and started the war in Vietnam which is killing off at least a hundred Americans and a thousand Vietnamese every week, and we are trying to stop it. 
Marshal: Sit down

Mr. Dellinger: And you call that ranting and raving and screaming because we speak the truth

Marshal: Mr. Dellinger, sit down, please

Prosecution: Your Honor, in the American system there is a proper way to raise such issues and to correct them

Mr. Dellinger: That was the proper way with Fred Hampton, wasn't it? (Clavir and Spitzer 1971, pp. 468-469).

What we witness here is a collision of two universes, one inhabited by the accused, and another by the accuser. We witness the complete absence of a common legal ground, a rapport de justice, between the values and causes represented by the prosecution and those represented by the defendants. Unlike ordinary criminal trials in which the parties to the trial accept the normative legitimacy of the existing political order and its instituted forms of justice, this trial brought into the courtroom parties who hold radically different views about the state, public authority, society, and the very meaning of the good life. From the government's point of view, the accused are defendants suspected of criminal conduct. Like any defendant before the law, they are called to account according to time-honoured doctrines, principles, and traditions of criminal justice. Accordingly, the Vietnam War, whatever its relevance and significance to the conduct of the defendants, 'has nothing whatsoever to do with the charges in this indictment' (Clavir and Spitzer 1971, p. 468). The prosecution repeatedly objected to references to the Vietnam War, institutional racism, or the broader ideological and political issues central to the tumult of the 1960s as unintelligible to the trial's internal logic and its communicative framework. For the defendants, however, the Vietnam War is not just an issue of theoretical or marginal relevance to the ultimate question on trial but rather a central one. Here is an exchange that captures the centrality of the Vietnam War to the defence:

Counsel: Mr. Schaller, is it an obscenity for the mayor of a major metropolitan area to advise his police to shoot to kill all arsonists and shoot to maim all looters?

Prosecution: Objection.

The Court: I sustain the objection.

Counsel: Do you consider it an obscenity for the United States Government to use napalm in the bombing of civilians in North Vietnam?

Prosecution: Mr. Weinglass can't be serious in contending that these questions are proper on this re-cross examination.

Counsel: That is perhaps my most serious question in this trial. (Levine et al 1970, p. 109)

Given the radically contrasting views held by the parties not just on the question of what is legally relevant and intelligible but also on the fundamental normative assumptions about the nature of the American body-politic, the trial failed to serve as an appropriate communicative framework for considering and adjudicating the political and ideological disputes on trial in terms of legal rules. The basic normative assumption that posits the trial as 'the moment in which we apply to ourselves 
the norms we have given ourselves' (Christodoulidis 2004, p. 186) collapses the moment the accused orients itself to legal spaces, moments and discourses strategically, calling into question the legitimacy, givenness and self-evidence of the system. The defendants' strategic engagement with the law and the court changes the very nature of the trial from litigation to what the philosopher Jean-François Lyotard aptly termed a différend (1988, p. 9). In his formulation, '[A] case of différend between two parties takes place when the "regulation" of the conflict that opposes them is done in the idiom of one of the parties while the wrong suffered by the other is not signified in that idiom' (Lyotard 1988, p.9). 'As distinguished from litigation', Lyotard writes, 'a differend [différend] would be a case of conflict, between (at least) two parties, that cannot be equitably resolved for lack of a rule of judgment applicable to both arguments' (1988, p. xi). In our case, the conflict between the accused and the accuser is regulated in the idiom of the state and this idiom, by its very formulation, is incapable of hearing, acknowledging, recognising, and redressing the wrongs suffered by the accused. In his article, 'The Inertia of Institutional Imagination: A Response to Roberto Unger', Christodoulidis (1996) examines the ways in which law's self-referential logic and normative closures are institutionally imagined and used to render certain forms of claims unintelligible and unspeakable in the courtroom. 'The system's cognitive openness, in fact, the cognitive openness that can be nothing else except systemic', Christodoulidis writes, 'is premised on the system's closure, its ability to reduce the complexity it is faced with' (1996, p. 384). Law's gate-keeping discourses and practices function to ensure law's discursive boundaries are safeguarded and secured from subversive intrusions, drawing permeable but ever-shifting boundaries between inside and outside, the stranger and the familiar, the legal and the political, through systemic distinctions between the 'democratic public spheres' available for legitimate political contestations, on the one hand, and the juridical sphere where political action is juridically deactivated, on the other. According to this logic, any claim that fails to subscribe to law's conceptual and technical categories and its economies of representation will be the object of its fundamental premise-closure. Before any substantive questions are taken up, the claim must be intelligible to the system and should be presented in a form that the system could recognise and hear. In other words, legal doctrines, rules, principles, procedures, and institutions require defendants who resist their own mode of construction as subjects and the framework of subjection, to operate from within law's discursive boundaries. Writing about this logic of silencing at work in the Chicago Conspiracy Trial, Pnina Lahav says this about the discourse of the rule of law: 'Few would disagree that the rule of law, as an abstract ideal, is glorious. The dialogue's considerable appeal may lie precisely in the fact that it does not engage in making the invisible visible, but rather in a cover-up' (2004, p. 400).

When the court refused to hear their account of the Vietnam War and deprived them of their right to give an account of themselves and the charges brought against them, Kunstler told the judge that he 'would like to move for a mistrial' (Clavir and Spitzer 1971, p. 468). The judge rejected Kunstler's motion before he even heard it and directed the Marshal to have him sit down. Indignant and frustrated, Kunstler cried, 'Every time I make a motion am I going to be thrown in my seat when I argue it?'(Clavir and Spitzer 1971, p. 468). Unable to find a common ground or a mutually 
acceptable framework of communication to explore the issues central to the trial, the defendants began to operate from outside law's confining frameworks to expose the hypocrisy at the heart of the government's case. Defendant Dellinger accuses the court, the symbolic personification of law and American legal culture, of hypocrisy: 'You let Foran give a foreign policy speech, but when he tries to answer it, you interrupt him and won't let him speak. There's no pretence of fairness in this court' (Clavir and Spitzer 1971, p. 468). While Dellinger speaks without the authority to speak, his interventions bring to the fore the uneven distribution of voice and problematic criteria of intelligibility applied by the court. The Court, whose normative function is to adjudicate social conflict in the realm of reason and the ideal, sustained objections by the government to secure the established order and its instituted forms and boundaries of criminal justice from disruptive intervention. In protecting and securing the law and its vulnerable frontiers from subversive interventions, the judge turned to law's circular and self-referential logic and declared their speech legally unintelligible. When the defendants persisted in speaking on their behalf, the judge ordered the Marshal to use physical violence to restore order and decorum, disclosing the sovereign violence at the core of public authority, and implicit in the political and economic symbolizations of the modern state.

The defendants, who have already described the trial as the continuation of state violence by legal means, are now accusing the judge of inciting a riot in the courtroom. Abbie Hoffman, one of the eight defendants, told a journalist during the trial: 'I think we're seeing the same type of dinosaur thinking in the courtroom that Mayor Daley employed in the streets of Chicago' (Linder 2020). Recall also that the Walker Commission has already concluded the events in Chicago were a 'police riot'. Dellinger grabs the opportunity and intervenes to expose this hypocrisy, a contradiction at the heart of the government's case, not from the lectern but the defence table. 'Force and violence! The judge is inciting a riot by asking the marshal to have him sit down', he declares (Clavir and Spitzer 1971, p. 469). The same law enforcement agencies that 'rioted' in Chicago decided to put protestors on trial for conspiracy to incite a riot. By accusing the court sitting in judgment over the accused for charges of inciting a riot in the courtroom, the defendants are exposing the contradiction at the core of the American justice system. This is a strategy Emilios Christodoulidis, following the controversial French lawyer, Jacques Vergès, calls 'rupture' (Christodoulidis 2009).

In 'Strategies of Rupture,' a seminal scholarship that urges a 'return to thinking of critical legal intervention in political strategic terms', Christodoulidis argues that 'if the State that calls to account those who commit such crimes is also their perpetrator, its legitimacy to judge them is withdrawn and its attempt to monopolise them can be nothing but a political-ideological move' (Christodoulidis 2009, p. 9). Drawing on Verges, Christodoulidis further notes that the strategy of rupture as mobilized within the courtroom and beyond consisted of identifying and appropriating disjuncture, contradictions, and points of fissures in the system to 'place society in contradiction with its principles' (Christodoulidis 2009, p. 4). Having identified closure as the system's default normative position, Christodoulidis draws our attention to the fundamental indeterminacy of the legal order, the rights discourse and the proliferation of discursive fissures, cracks, and points of tensions and contradictions that 
provide resistant subjects an opportunity for a political-strategic intervention that are institutionally relevant (Christodoulidis 1996, p. 10). Characterising the strategy of rupture as a form of immanent critique, Christodoulidis insists that the only form of resistance that counts as truly resistant, 'neither reducible to-nor co-optable bythe order it seeks to resist', and offers redress within the terms of the law, is one that can 'break incongruently, irreducibly so, with the order' and the ideology it resists (Christodoulidis 2009, p. 10).

In the Chicago Conspiracy Trial, the defence engaged the law in political-strategic terms, not as a horizon of communicative exchange but as means of political critique and an object of ideological confrontation. Faced with an idiom that is incapable of recognizing his claims, Dellinger openly defies the judge and operates from outside the terms of engagement: 'After such hypocrisy, I don't particularly feel like being quiet. I said before the judge was the chief prosecutor, and he's proved the point' (Clavir and Spitzer 1971, p. 469). The judge's resort to violence to restore the imperative by suppressing certain forms of truths speaks to the very nature of sovereignty itself. Dellinger's unexpected intervention unmasks not just the violence in the courtroom but also the ambiguous and groundless nature of sovereign power: 'There's no pretence of fairness in this court'. The court's reliance on violence unmasks this empty space at the base of the symbolic authority of law: 'All you're doing is employing a riot-employing force and violence to try to keep me quiet. Just like you gagged Bobby Seale because you couldn't afford to listen to the truth that he was saying to you. You're accusing me. I'm a pacifist' (Clavir and Spitzer 1971, p. 469). By pointing to the willingness of the state to be mercilessly violent, Dellinger's interventions expose the kinds of assumptions and unchallenged modes of thought and reasoning upon which the system's legitimacy rests. As Saul Newman writes, judicial violence 'embodies a space of exception-a "no man's land" between legality and illegality-in which law is both preserved and transgressed through the very violence and arbitrariness with which it is enforced' (Newman 2004, p. 573). When Dellinger says, 'you're accusing me of violence, and you have a man right here, backed up by guns, jails, and force and violence', he is making visible this very violence and arbitrariness for which law does not and cannot account (Clavir and Spitzer 1971, p. 469). When the system represented by the prosecution's case invokes criteria of legal intelligibility to exclude certain forms of stories and truths from being told, Dellinger points out the hypocrisy of the justice system and its intimate and structural affinity with violence.

When the state's source of legitimacy came under a tremendous attack, the prosecution moved to remind the Court and the jury about the integrity and continuity of the system by recounting the glorious and culturally hegemonic history of the American judiciary. The prosecution knows that the unity and continuity of the established political order and the instituted forms of justice are maintained through official histories that impose an official meaning on the past while silencing competing interpretations of those historical experiences. In an attempt to further silence and demean the defendants, the prosecution argued, 'Your Honor, this is the American judicial system, and it's worked very well for two hundred years, and it's not going to change now for these people'. The defence countered, sarcastically, by drawing attention to the lost voices and forgotten experiences relating to the judiciary's role 
in rationalizing and legitimizing racist and oppressive discourses. Mr Dellinger replied, 'Yes, [the judiciary] kept the black people in slavery for two hundred years and wiped out the Indians and kept the poor people in problems and started the war in Vietnam which is killing off at least a hundred Americans and a thousand Vietnamese every week, and we are trying to stop it' (Clavir and Spitzer 1971, p. 469). By drawing attention to those silenced bodies of experiences and memories, Dellinger offers a counter-historical account of the system that is antithetical to the state, focusing on its founding violence and the exclusions, oppressions, and marginalization the judicial system helped to rationalize and legitimize. The reference to slavery, the genocide of the Indians, and the gagging and binding of Bobby Seale to a metal chair in the courtroom were practices radically at odds with the narrative of the government and make the violence of the state, that is at once at the root and all across the normative structure of the system, empirically accessible and visible.

By tapping into the disruptive power of these silenced and excluded historical experiences, Dellinger's intervention revives the hidden and marginalized bodies of experience and creates new historical perspectives and normative attitudes. In his account of counter-history in the context of $17^{\text {th }}$-century European race-wars, Foucault makes a point relevant to the issue at hand: 'beneath the forms of justice that have been instituted, the order that has been imposed, [lies] the forgotten past of real struggles, actual victories, and defeats which may have been disguised but which remain profoundly inscribed' (Foucault 2003, p. 56). While the prosecution projects a history of American judiciary consistent with the public right of sovereignty, the defence draws attention to the silences and omissions and challenges the prevailing forms of remembering and forgetting. Dellinger insists on those marginalized, dejected, and buried experiences that have become the hidden scars of long-forgotten struggles against racism and injustice and expresses his frustration with the Judge's indifference to their cries: 'And you call that ranting and raving and screaming because we speak the truth' (Clavir and Spitzer 1971, p. 469). Here, Dellinger is interested, to use Foucault's formulations, 'in the battle cries that can be heard beneath the formulas of right, in the dissymmetry of forces that lies beneath the equilibrium of justice' (Foucault 2003, p. 56).

Unable to openly dismiss the truths and accounts of the defendants, the prosecution appears to concede that there may be a legitimate ground for the objections but that the judicial system is not the appropriate platform for doing so. The prosecution states, 'in the American system there is a proper way to raise such issues and to correct them' and this is not it (Clavir and Spitzer 1971, p. 469). The judicial system is not space where the Vietnam War and other broader political questions are debated and addressed. There is a 'proper governmental system' where those explicitly political questions, which are legally unintelligible, could be addressed. For these defendants, however, there is no 'proper governmental system' through which they can 'raise' issues of foremost importance such as the Vietnam War, institutional racism, and broader questions of social justice. In fact, they were on trial for trying to present their grievances through 'the proper governmental system', i.e., through the exercise of their right to protest. Dellinger lays bare the emptiness of this claim of 'proper governmental system' by drawing attention to the murder of Fred Hampton, the Chairman of the Illinois Chapter of the Black Panther Party, by police while 
in bed in predawn raid (Burrough 2016, pp. 84-85). The state assassinated Fred Hampton when it could have arrested him and put him on trial for any wrongdoings (William 2019). It did not. It murdered him, in what scholars now widely consider political assassination (Stubblefield 2005, pp. 60-61). Confronting the government with a contradiction that cannot be ignored, displaced, or overcome by the system, Dellinger calls the government to account: 'That was the proper way with Fred Hampton, wasn't it?' Dellinger here is tapping this disjuncture between the normative principles of equality, liberty, and the pursuit of happiness that underpin American's founding, and the actual material practices of the Republic. In exposing this inconsistency, his aim is to bring about a rupture, to place the American society in contradiction to its founding ideals and principles. His goal, to use Christodoulidis' poignant formulation, is 'to hold up the system to its own claims, force it to face up to its stated principles, to equality, to procedural fairness, etc., where this measuring up forces it beyond what it can possibly "contain" within its economy of representation' (2009, p. 6). The exceptional nature of sovereign power and its uncontrollable excesses and overreaches means that there is no such thing as a 'proper governmental system' through which legitimate questions are raised and addressed. Drawing attention to Fred Hampton's death was important not just because his assassination collides head-on with the government's narrative that there is 'a proper governmental way' through which claims for justice and equality can be addressed but also because of the horrific treatment of Bobby Seale, the Chairman of the Black Panther Party, by the judge. Following angry confrontation over the denial of Seale's right to representation by a counsel of his choice or self-representation, the judge ordered the gagging and binding of Seale, in what was described as 'a spectacle worthy of Artaud and Brook' (Lahav 2004, p. 399).

Faced with a communicative framework that rendered their idioms unintelligible, defendants turn to a performative logic of disruption whereby claims and accounts that cannot be captured within the trial's logic of deliberation are produced and filtered into the court of public opinion performatively. Whenever the court excluded their testimony as political, inadmissible, or irrelevant, they used various modes of communication-sarcasm, irony, humour, music - to convey their view of the issues to the American public. Throughout the trial, the defendants sought to resist the silencing effects of the deliberative framework and the judge's hostile attitude through a series of accidental, impulsive, and spontaneous spectacles that turned the courtroom into a site of guerrilla theatre. In one instance, two of the defendants showed up to court wearing judicial robes in protest of the Judge's revocation of Dellinger's bail. When asked to remove their robes, they took them off and stomped on them in a scene of extraordinary defiance that appeared spontaneous. On another occasion, Abbie Hoffman unfurled the flag of the Viet Cong, also known as the National Liberation Front (FNL), on the defence table, provoking a tag-ofwar with court marshals. The defendants continually disrupted judicial decorum not only by speaking without permission but also by engaging in a range of creative, spontaneous, and unexpected actions: bringing a birthday cake to the courtroom, blowing kisses to the jury, munching jellybeans, and calling the Judge 'Julie', 'liar,' 'hypocrite,' and 'fascist dog' (Linder 2017). These behaviours provoked the judge even further, leading him to order the binding and gagging of Bobby Seale-in one 
of the most outrageous scenes to take place in a U.S. courtroom. Summing up the defence's attitude towards the judge and the judicial process, Jerry Rubin, said: 'Our strategy was to give Judge Hoffman a heart attack. We gave the court system a heart attack, which is even better' (Cain 2019, p. 124).

\section{Scene II: 'I Will not Permit Singing in this Courtroom': Performative Disruption}

On 22 January 1970, the defence called the famous folk singer, Judy Collins, to the stand. Asked to explain to the Court and the jury what she did at the inaugural meeting of the 'Yippie Movement', Collins began her testimony by singing, breaking with established conventions and provoking a furious objection from the court and the prosecution.

Mr. Kunstler: Now, Miss Collins, I call your attention to March 17 of 1968 at approximately noontime on that date. Do you know where you were?

The Witness: I was at the Americana Hotel in New York City attending a press conference to announce the formation of what we have now come to know of as the Yippie Movement

Mr. Kunstler: Now what did you do at that press conference?

The Witness: Well---[sings] Where have all the flowers-

The Court: Just a minute, young lady.

The Witness: [sings] "---where have all the flowers gone?"

Marshal J: I'm sorry. The Judge would like to speak to you.

The Court: We don't allow any singing in this Court. I'm sorry.

The Witness: May I recite the words?

Mr. Kunstler: Well, your Honor, we have had films. I think it is as legitimate as a movie. It is the actual thing she did, she sang "Where Have All the Flowers Gone," which is a well-known peace song, and she sang it, and the jury is not getting the flavor.

The Court: You asked her what she did, and she proceeded to sing.

Mr. Kunstler: That is what she did, your Honor.

The Witness: That's what I do.

The Court: And that has no place in a United States District Court. We are not here to be entertained, sir. We are trying a very important case.

Mr. Kunstler: This song is not an entertainment, your Honor. This is a song of peace, and what happens to young men and women during wartime.

The Court: I forbid her from singing during the trial. I will not permit singing in this courtroom.

Mr. Kunstler: Why not, Your Honor? What's wrong with singing? (Clavir and Spitzer, 1971, p.460)

This is a testimony aimed at disrupting the accepted idiom of intelligibility and express what cannot be captured through ordinary forms of courtroom testimony. By going against the established juridical cannon around proper decorum and law's privileging of content over form, the defendants practice a kind of epistemic 
disobedience to disrupt the state's narrative that the accused are nothing more than a bunch of criminal thugs determined to wreck the peace and wellbeing of American society. Disobedient and deliberately provocative, the defence ignores the standard testimonial practice and introduces music as an alternative way of witnessing that is not reducible to speech. While the form of her testimony, i.e., the use of music as opposed to speech, is aimed to disrupt the canons and categories of Western juridical conventions, the substance of the song goes to the very core of the defendant's political message.

The song serves both a political and a legal purpose. Legally, it serves as evidence repudiating the prosecution's claim about a violent conspiracy by the defendants. The defendants' position is that they 'are entitled to the benefit of all of the legal evidence they have indicating their innocence, writings as well as spoken words' (Clavir and Spitzer 1971, p.460). When the judge stopped the witness from singing, Kunstler challenged the judge's decision: 'your Honour, we have had films. I think it is as legitimate as a movie' (Clavir and Spitzer 1971, p.460). In other words, if a film that is not available for cross-examination can be accepted as legitimate evidence, on what terms can the court exclude singing or a recitation of the words by a human subject? For the judge and the prosecution, this mode of witnessing or speaking in the courtroom is irrational, deviant, and falls far short of serious speech consistent with proper decorum. This marginalisation of musicological discourse at trials has been critiqued by recent social-legal and critical legal scholarship that urged attention to 'the role of the acoustic' in law (Parker 2015). When the Judge says that 'the [song] has no place in the United States District Court' and 'We are not here to be entertained', or the prosecutor objects that the song 'doesn't have a thing to do with this lawsuit nor what my profession is', they are simply reiterating the mainstream juridical account that 'performance is identical to theatre, and that theatre is identical to entertainment, and as such is a trivial and unseemly enterprise' (Hibbitts 1996).

Politically, the song contests the accepted interpretations and paradigms of juridical thought, while also highlighting the centrality of peace to the conducts of the defendants. When the judge dismissed the defendant's preferred mode of testimony claiming that 'we are trying a very important case', Kunstler seizes the moment: 'This song is not an entertainment, your Honor. This is a song of peace, and what happens to young men and women during wartime', returning the Vietnam War back on the court's agenda (Clavir and Spitzer 1971). Kunstler and his clients are seeking to burn into the consciousness of the American public but appealing to the conscience of the public required more than just a rational argumentation. In order to present an effective counter-discourse that can compete for a hearing against the 'truth-bearing' discourse of the system, the strategy must operate not only within the confines of the deliberative paradigm, but also at the margins of legality, at the interstices of legality and illegality, incongruently, and poetically, through humour, irony, wit, jokes, and music, to evoke the desired power-effect. It must move beyond the realm of rational argumentation to anticipate the different ways in which the subject is constructed, its agency foreclosed, and its critique a priori disqualified. Kunstler says: 'the jury is not getting the flavour'. The song, therefore, represents such an appeal to the unexpected, and the non-rational to expose the limit of the rational. 
By returning to the war-peace agenda, an issue the prosecution argues is legally irrelevant and is therefore cannot be heard, the defence seeks to present the Vietnam war and the broader questions of racism and governmental accountability as central to their defence. At the political level, then, the song by Judy Collins is a performative action that identifies the defendants with the discourse of peace and the state and the court system with war and concretizes this in the mind of the public. The decision to introduce a song as a form of testimony is not driven by its exculpatory potential so much as its potential to create possibilities for inter-subjective communication. Insofar as the possibilities for communication and understanding between the sovereign and the subject are limited by the instituted criteria of intelligibility, i.e., by the modes of thought and forms of reasoning that organizes and structures communications between the subject and sovereign, the possibility of communication depends on a resignification of the criteria of intelligibility and the reinvention of new and disobedient subjects. Put differently, if the terms of convincing a political adversary about the validity of one's claim are limited by the instituted paradigms of communication, then the possibility of communication and understanding depends on the disruption of that paradigm and the performative reinvention of a new one (Kulynych 1997, p. 335).

\section{Scene III: 'I am a Cultural Revolutionary': Utopia in the Courtroom?}

During the opening statement, defence counsel Leonard Weinglass told the jury that the protest groups that came to Chicago in the summer of 1968 were not only antiwar, anti-racism, and social justice activists. He said: 'there was also another group of people who came here not for the purpose of protest, and not even for the purpose of demonstrating, in fact, but for the purpose of showing the public, and the leaders, and the rulers of this country that there was emerging within the country a new culture, and this group was generally called the Yippies' (Clavir and Spitzer 1971, p. 18). Founded by Abbie Hoffman and Jerry Rubin in January 1968, the Yippies were a counter-cultural revolutionary group of predominantly young people who were frustrated with what they saw as the abject absurdity of American politics and culture. Hoffman and Rubin saw culture and politics as inexorably linked and deployed non-traditional protest methods such as performance, spontaneity, mischief, and theatre to amplify their voices. Hoffman and Rubin believed that the best way to counter and disrupt the cultural norms of society and the smugness of the liberal political establishment was through guerrilla theatre in which satire, drama, improvisation, and music become alternative ways of articulating a new vision of the future or a different narrative of the normative. For example, in 1967, during an anti-war protest in Washington, DC, Rubin and Hoffman, together with the poet Allen Ginsberg, organised a public exorcism of the Pentagon (Brigham 2008, p. 110). During the 1968 anti-war protests in Chicago, the Yippies staged a counter-convention they called the 'Festival of Life', a carnivalesque music and theatre event full of outlandish protest tactics and stunts central to their strategies of disruption and transformation. While delegates to the Democratic National Convention cast votes to nominate the Democratic Party's presidential candidate inside Chicago's International Amphitheatre, 
the Yippies nominated a pig named Pigasus as their presidential nominee in Lincoln Park, a calculated stunt Abbie Hoffman would later describe as 'total theatre' (Wasson 2017, p. 129).

On December 23, 1969, the defence called Abbie Hoffman, co-founder of the Yippies and one of the eight defendants, to the witness stand. Once again, the defence's strategy was to use one of the ordinary devices of criminal law, i.e., their right to direct examination, to highlight this new emerging culture, to perform new ways of thinking, acting, and being in the world. However, as we shall see, they did so not simply from within the trial's deliberative framework but simultaneously from outside it. In the hands of the defence, direct-examination is repurposed and mobilized to set out the defendants' vision of a new society and a new nation:

The Counsel: Will you please identify yourself for the record?

The Witness: My name is Abbie. I am an orphan of America.

The Prosecution: Your Honor, may the record show it is the defendant Hoffman who has taken the stand?

The Court: Oh, yes. It may so indicate ...

The Counsel: Where do you reside?

The Witness: I live in Woodstock Nation.

The Counsel: Will you tell the Court and jury where it is?

The Witness: Yes. It is a nation of alienated young people. We carry it around with us as a state of mind in the same way as the Sioux Indians carried the Sioux nation around with them. It is a nation dedicated to cooperation versus competition, to the idea that people should have better means of exchange than property or money, that there should be some other basis for human interaction. It is a nation dedicated to--

The Court: Just where it is, that is all.

The Witness: It is in my mind and in the minds of my brothers and sisters. It does not consist of property or material but, rather, of ideas and certain values. We believe in a society--

The Court: No, we want the place of residence, if he has one, place of doing business, if you have a business. Nothing about philosophy or India, Sir. Just where you live, if you have a place to live. Now you said Woodstock. In what state is Woodstock?

The Witness: It is in the state of mind, in the mind of me and my brothers and sisters. It is a conspiracy. Presently, the nation is held captive, in the penitentiaries of the institutions of a decaying system.

...

The Counsel: Can you tell the Court and jury what is your present occupation?

The Witness: I am a cultural revolutionary. Well, I am really a defendant--fulltime.

The Counsel: What do you mean by the phrase 'cultural revolutionary?'

The Witness: Well, I suppose it is a person who tries to shape and participate in the values, and the mores, the custom and the style of living of new people who eventually become inhabitants of a new nation and a new society through art and poetry, theatre, and music (Clavir and Spitzer 1971, pp. 344-345). 
We witness here a strategic political intervention that exploits the trial's indeterminate, spatial, discursive, and temporal openness to articulate a new utopian vision of society. Although the system expects the legal subject to act responsibly, i.e., respecting authority and viewing it as its mirror-image, Hoffman here breaks with sovereignty's expectations of obedience and exercises political agency. His creative intervention appropriates the system's discursive openness at the earliest available opportunity to name a new society, and define new normative standards, and control meaning. Ordinary questions reconfigured to generate extraordinary answers.

Hoffman begins his testimony in a subversive style, identifying himself as 'an orphan of America,' a resident of 'Woodstock Nation,' and a 'cultural revolutionary.' In this innovative and agonistic intervention, the strategy is at once oriented towards 'carving out space for acting' and bringing the internalized norms that make our identities self-evident back into the realm of contestation. Hoffman exploits the indeterminacy of the moment to enable and encourage people to see new ways of being and acting in the world, new possibilities and imaginations of the legal world (Young 2010, p. 317). His defiant responses to standard questions transcend technical legal debates and procedural imperatives, becoming at once performative acts of disruption and self-recreation. Hoffman's testimony can be seen as the kind of 'world-disclosing' and 'identity-creating' moment that Jill Dolan calls a 'utopian performative' (Dolan 2005). In 'Utopia in Performance,' Dolan uses the phrase 'utopian performative' to capture those,

small but profound moments in which performance calls the attention of the audience in a way that lifts everyone slightly above the present, into a hopeful feeling of what the world might be like if every moment of our lives were as emotionally voluminous, generous, aesthetically striking, and intersubjectively intense. (Dolan 2005, p. 5)

Hoffman's intervention here is precisely the kind of moment Dolan describes. As a 'utopian performative,' Hoffman's intervention transforms law's procedural, spatial, and temporal coordinates into an arena of world-making, proclaiming new rights and new ethical and moral standards, declaring new and different ways of naming and perceiving a world substantively different from the present.

In imagining himself as a resident of what he calls the 'Woodstock Nation,' a utopian nation that does not have a concrete political existence yet, one that exists as a 'state of mind,' Hoffman is disclosing a different world governed by a new epistemic standard: 'a new nation... dedicated to cooperation versus competition, to the idea that people should have better means of exchange than property or money, that there should be some other basis for human interaction' (Clavir and Spitzer 1971, p. 344). His creative acts of self-naming bring ethical and political concerns into a sharp focus and gesture towards new forms of imagining and renewing beyond the present.

Hoffman's performances are also transformative in the sense that they are identity-creating. In identifying himself as a 'Cultural Revolutionary,' he is bringing into being a new citizen, a new identity, a new political subjectivity that is defiant and resistant to the apparatus of subjection. He defines a cultural revolutionary as 'a person who tries to shape and participate in the values and mores, the customs and the style of living of new people who eventually become inhabitants of a new nation and 
a new society through art and poetry, theatre, and music' (Clavir and Spitzer 1971, p. 345) Apart from reconstituting the defendants as subjects capable of resistance to disciplinary technologies that constitute their identity, his performative response extends the realm of contestation beyond self-recreation to encompass the norms of the ideal liberal subject as something that can no longer be taken for granted.

Arguing against the absorption of constituent power into constituted power, Christodoulidis insists that 'the irreducibility of the political to politics, of the constituent to the constituted, underpins our ability to break from, to imagine otherwise, and to renew beyond modalities of what has already been instituted' (Christodoulidis 2007, p. 195). In imagining and proposing a new nation and a new society beneath the old, Hoffman in his role as a witness is resisting the reduction of the constituent to the constituted, and he is seeking to break from, or imagine 'beyond modalities of what has already been instituted' (Christodoulidis 2007, p. 195). Condemning the usurpation of the power of the constituent and naming a different kind of society and an alternative way of being and acting in the world, the defendant brings into being a disruption that defies containment by the system. He appropriates the transformative opportunity of the moment to call into being a "nation of alienated young people' who believe in society, and consisted of ideas and values, as opposed to 'property or material'. He also proposes new epistemic standard'art and poetry, theatre, and music' that would govern this new society and nation. Through such innovative intervention at this early stage in his testimony, Hoffman's defiant action secures space not only to disrupt the confining idioms that structure the dialogue within the courtroom but also to transform the identities and normative standards within society as such.

In this way, Hoffman's performative resistance appropriates law's discursive, temporal, and spatial indeterminacy to draw public attention to the power of new ideas in political transformation. His interventions do not seek to represent or express something essential about him or his movement; rather, his actions seek, through his performative testimony itself, to bring into being the very ideals he invokes - a new nation, a new society, and new normative standards. As James Boyd White writes, 'every speech act is a way of being and acting in the world that makes a claim for its own rightness, which we ask others to respect' (White 1994, p. xi). Regardless of its utopian form, Hoffman's disruptive strategy demonstrates that 'we can still act' though these actions are always contingent. As Frederic Jameson argues, 'the secession of utopian imagination from the everyday empirical being takes the form of a temporal emergence and a historical transition' (Jameson, 2005, p. 85).

\section{Conclusion: Toward the Use of the Courtroom as Site of Political and Ideological Critique}

According to normative legal theory and mainstream legal practice, the courtroom is a geometrically delineated legal space of truth and justice elevated above and beyond the expediency of politics. Within this normative frame, the proper purpose and function of the criminal trial is to establish the truth of what happened, produce a decision on the guilt or innocence of the accused, and render justice through an 
act of judgment. In a major project dedicated to developing a normative theory of the criminal trial, Duff and others identify the concept of calling to account as the central feature of a normative theory of the criminal trial (Duff et al. 2006, p. 3). They argue that in order for public authority to justify its authority to call individuals to account and pass a sentence, the individuals must see themselves as authors of the law and must be treated as addressors and addressee of the rules and principles applied during the trial. This conception of the criminal trial is underpinned by certain normative understandings of the relationship between the social contract, sovereignty, law and the subject whereby the subject considers herself to belong to the political community and recognises the legitimacy of the social contract, the sovereign power of the authorities, and the norms created by them. In this regard, Christodoulidis argues that the 'democratic legitimation of the trial presupposes and insists upon a certain continuity between legislation and adjudication. The trial is the moment in which we apply to ourselves the norms we have given ourselves' (Christodoulidis 2004, p. 186). Emphasizing the centrality of the deliberative model to the legitimacy of the democratic state and its authority to punish one of its citizens, Klaus Günther states that 'the democratic process is distinguished from all other forms of legitimation of norms in unifying the notion of citizen and the notion of legal person in the concept of the deliberative person' (Günther 2001, p. 11).

However, as we have seen in the preceding discussion, such a normative understanding of the criminal trial raises a number of profound questions to the coherence and integrity of the deliberative model. This is particularly true when the accused and the accuser hold radically different views about the social contract, the political community, and its laws. The record of the Chicago Eight Conspiracy Trial demonstrates that the courtroom is a highly performative space with considerable social, political and cultural functions. As we have seen, the defendants effectively reconceptualised normative notions of sovereignty, the subject, and law, and engaged with the system in strategic-political terms. Recognizing the impossibility of communication and understanding between the accused the accuser, the defendants resorted to agonistic modes of resistance to turn the courtroom into a classroom, to historicize the law, and keep the issue of Vietnam War, institutional racism, and social justice at the forefront of their defense and the public debate. While the prosecution consistently objected to references to the Vietnam War, police violence, and racism as irrelevant to the case before the court, and therefore irrational and legally unintelligible speech, the defense disobeyed the court and the government and continued to link their conduct during the Democratic National Convention to the pursuit of peace, equality, and justice. By coupling their trial with broader questions of war, racism, and social justice, they activated politics where politics is least active. Going beyond a strict legal defence against the prosecution's case, they used the opportunity offered by the trial to engage in a broader critique of the United States government and its policies. Working with and against legal doctrines, discourses, and procedures, they exposed the ways in which gate-keeping discourses central to the architecture of the democratic state have been used to sustain and preserve established relationships of power and inequality.

What this trial and the analysis offered in this article shows is that contrary to law's normative closures and silencing criteria of intelligibility, the courtroom is 
still a powerful site for political critique and struggle. The defendants creatively appropriated the tension, cracks, and fissures within the system to create conditions for transformative interventions. By disentangling law, sovereignty and subjectivity from the question of what is good, rational, and true, they called into question the notions, domains, concepts, and analytic frameworks by which law disables contestations and closes possibilities for change and becoming. In other words, they allowed us to recognise law, sovereignty and the subject, not as normative, fixed and static but as contingent power-knowledge constellations, leaving the future open, unpredictable, and un-closable.

Fifty years on, the Chicago Conspiracy Trial is still remembered as one of the most captivating and memorable courtroom showdowns of the twentieth century. It was not a sensational trial of a celebrity or a serial murderer but a political trial in which deeper questions about structural racism, economic inequality, state violence, and social justice struggled with the law for hearing and visibility. It was a trial that brought together the Nixonian worldview of law and order and radical activists who claim to believe in creating new societies that are more equal, substantively fairer, and democratic. In the era of Make America Great Again (MAGA) and Black Lives Matter, the Chicago Conspiracy Trial and the culture wars of the 1960s contains lessons relevant to contemporary politics in the US and beyond.

Acknowledgements Partial financial support was received from the University of Glasgow to prepare an earlier version of the paper.

Open Access This article is licensed under a Creative Commons Attribution 4.0 International License, which permits use, sharing, adaptation, distribution and reproduction in any medium or format, as long as you give appropriate credit to the original author(s) and the source, provide a link to the Creative Commons licence, and indicate if changes were made. The images or other third party material in this article are included in the article's Creative Commons licence, unless indicated otherwise in a credit line to the material. If material is not included in the article's Creative Commons licence and your intended use is not permitted by statutory regulation or exceeds the permitted use, you will need to obtain permission directly from the copyright holder. To view a copy of this licence, visit http://creativecommons.org/licen ses/by/4.0/.

\section{References}

Achenbach, Joel. 2018. 'A party that had lost its mind': In 1968, Democrats held one of history's most disastrous conventions. https://www.washingtonpost.com/news/retropolis/wp/2018/08/24/aparty-that-had-lost-its-mind-in-1968-democrats-held-one-of-historys-most-disastrous-conve ntions/. Accessed 10 November 2021.

Arendt, Hannah. 1965. Eichmann in Jerusalem: A Report on the Banality of Evil. London: Penguin Books.

Brigham, Robert. 2008. Iraq, Vietnam, and the Limits of American Power. New York: Public Affairs.

Burrough, Bryan. 2016. Days of Rage: America's Radical Underground, the FBI, and the Forgotten Age of Revolutionary Violence. London: Penguin Publishing Group.

Cain, Scott. 2019. Folk Music and the New Left in the Sixties. Jefferson, NC: McFarland.

Casey-Maslen, Stuart. 2014. Weapons Under International Human Rights Law. Cambridge: Cambridge University Press.

Christodoulidis, Emilios. 1996. The Inertia of Institutional Imagination: A Response to Roberto Unger. The Modern Law Review 59 (3): 377-397. 
Christodoulidis, Emilios. 2004. The Objection That Cannot be Heard. In The Trial on Trial, vol. 1, ed. Anthony Duff, Lindsay Farmer, Sandra Marshall, and Victor Tadros, 179-202. Oxford: Hart Publishing.

Christodoulidis, Emilios. 2007. Against Substitution: The Constitutional Thinking of Dissensus. In The Paradox of Constitutionalism: Constituent Power and Constitutional Form, ed. Martin Laughlin and Neil Walker, 189-210. Oxford: Oxford University Press.

Christodoulidis, Emilios. 2009. Strategies of Rupture. Law and Critique 20 (1): 3-26.

Clavir, Judy, and John Spitzer, eds. 1971. The Conspiracy Trial. London: Cape.

Danver, Steven. 2011. Revolts, Protests, Demonstrations, and Rebellions in American History: An Encyclopedia. Santa Barbara: ABC-CLIO.

Farber, David, and Beth Bailey. 2001. The Columbia Guide to America in the 1960s. New York: Columbia University Press.

Dolan, Jill. 2005. Utopia in Performance: Finding Hope at the Theatre. Ann Arbor: The University of Michigan Press.

Duff, Anthony, Lindsay Farmer, Sandra Marshall, and Victor Tadros. 2004. The Trial on Trial, Volume 1, ed. Oxford: Hart Publishing.

Duff, Anthony, Lindsay Farmer, Sandra Marshall, and Victor Tadros. 2006. The Trial on Trial, Volume 2, ed. Oxford: Hart Publishing.

Duff, Antony R. 2018. The Real of Criminal Law. Oxford: Oxford University Press.

Farber, David. 1988. Chicago 68. Chicago: University of Chicago Press.

Farber, David. 2019. The Chicago Eight Conspiracy Trial at Fifty: Blind Justice in Polarized Times. Social Education 83 (3): 142-146.

Foucault, Michel. 2003. Society Must be Defended. London: Penguin Books.

Günther, Klaus. 2001. The Criminal Law of "Guilt" as Subject of A Politics of Remembrance in Democracies. In Lethe's Law: Justice, Law and Ethics in Reconciliation, ed. Emilios Christodoulidis and Scott Veitch, 3-16. Oxford: Hart Publishing.

Habermas, Jürgen. 1996. Between Facts and Norms: Contributions to A discourse Theory of Law and Democracy. Cambridge: The MIT Press.

Hibbitts, Bernard J. 1996. De-scribing Law: Performance in the Constitution of Legality. https:// www.law.pitt.edu/archive/hibbitts/describ.htm. Accessed 11 November 2021.

Jameson, Frederick. 2005. Archaeologies of the Future: The Desire Called Utopia and Other Science Fictions. London: Verso.

Kulynych, Jessica. 1997. Performing Politics: Foucault, Habermas, and Postmodern Participation. Polity 30 (2): 335. https://doi.org/10.2307/3235221.

Kusch, Frank. 2008. Battleground Chicago: The Police and the 1968 Democratic National Convention. Chicago: Chicago University Press.

Lahav, Pnina. 2004. Theatre in the Courtroom: The Chicago Conspiracy Trial. Law and Literature 16 (3): $381-474$.

Levine, Mark, George McNamee, and Daniel Greenberg. 1970. The Trial of the Chicago 7: The Official Transcript. New York: Simon \& Schuster.

Linder, Douglas O. 2020. The Famous Trials Website. http://www.famous-trials.com/chicago8/1339forant. Accessed 29 Jan 2021.

Mara, Will. 2010. Civil Unrest in the 1960s: Riots and their Aftermaths. Tarrytown: Marshall Cavandish.

McCarthy, Timothy, and John McMillian. 2010. Protest Nation: Words that Inspired a Century of American Radicalism. New York: The New Press.

Newman, Saul. 2004. Terror, Sovereignty and Law: On the Politics of Violence. German Law Journal 5 (5): 569-584.

Parker, James. 2015. Acoustic Jurisprudence: Listening to the Trial of Simon Bikindi. Oxford: Oxford University Press.

Popovici, Alice. 2018. Watergate: Who Did What and Where Are They Now? 16 October. History. com, https://www.history.com/news/watergate-where-are-they-now. Accessed 29 Jan 2021.

Schultz, John. 1993. The Chicago Conspiracy Trial. Chicago: The University of Chicago Press.

Sharma, Nick. 2016. The Chicago Conspiracy Trial and the Press. New York: Palgrave Macmillan.

Stewart, Lionel, Jaime Stewart, and Demar Brazil. 2011. Quiet Blood: Plantation to Prison. Bloomington: Xlibris, Corp.

Stubblefield, Anna. 2005. Ethics Along the Color Line. Ithaca: Cornell University Press. 
Taylor, David and Sam Morris. 2018. The Whole Word Is Watching: How the 1968 Chicago 'Police riot" shocked America and Divided the Nation. 19 August. The Guardian, https://www.theguardian.com/us-news/ng-interactive/2018/aug/19/the-whole-world-is-watching-chicago-police-riotvietnam-war-regan. Accessed 29 Jan 2021.

Wasson, Sam. 2017. Improv Nation: How We Made a Great American Art. New York: Houghton Mifflin Harcourt Publishing Company.

White, James. 1994. Acts of Hope: Creating Authority in Literature, Law, and Politics. Chicago: University of Chicago Press.

Young, Diana. 2010. Law and the Foucauldian Wild West in Michael Cimino's Heaven's Gate. Law, Culture and the Humanities 7 (2): 310-326.

Publisher's Note Springer Nature remains neutral with regard to jurisdictional claims in published maps and institutional affiliations. 